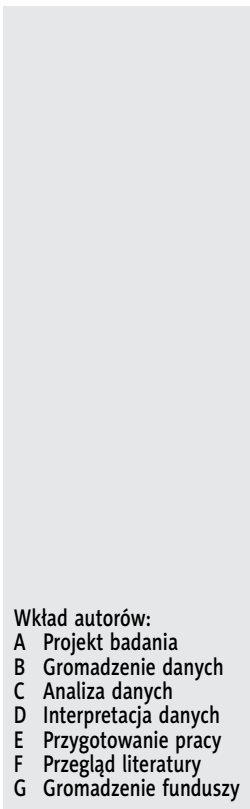

\title{
Ocena częstości występowania i uciążliwości szumów usznych u pacjentów poddanych operacyjnemu leczeniu otosklerozy - przegląd piśmiennictwa
}

\section{Evaluation of the prevalence and tinnitus distress in patients undergoing surgical treatment of otosclerosis - the overview}

\author{
Beata Dziendziel ${ }^{1 A B C D E F}$, Piotr H. Skarżyński ${ }^{1,2,3 A C D E}$, Joanna Rajchel ${ }^{1 C D}$, \\ Magdalena B. Skarżyńska ${ }^{1,2 C}$, Henryk Skarżyński ${ }^{1 A C D E}$ \\ ${ }^{1}$ Instytut Fizjologii i Patologii Słuchu, Światowe Centrum Słuchu, Warszawa/Kajetany \\ ${ }^{2}$ Instytut Narządów Zmysłów, Kajetany \\ ${ }^{3}$ Warszawski Uniwersytet Medyczny, II Wydział Lekarski, Zakład Niewydolności Serca \\ i Rehabilitacji Kardiologicznej, Warszawa
}

\section{Streszczenie}

Szumy uszne są częstym objawem występującym wraz z niedosłuchem w przebiegu otosklerozy. W pracy dokonano przeglądu literatury naukowej dotyczącej częstości występowania szumów usznych i ich uciążliwości wśród pacjentów poddanych chirurgii strzemiączka. Przeglądu piśmiennictwa dokonano na podstawie elektronicznych baz artykułów naukowych: PubMed, The Cochrane Library oraz Web of Science. Przedmiot zainteresowania stanowiły doniesienia na temat rozpowszechnienia szumów usznych w przebiegu otosklerozy, wpływu chirurgii strzemiączka na pooperacyjną zmianę w spostrzeganiu dolegliwości oraz rodzaju metod i narzędzi stosowanych przez autorów do oceny badanych zjawisk. Do przeglądu literatury włączono 13 artykułów. Stwierdzono, że w grupie pacjentów dotkniętych otosklerozą od 65\% do ponad $90 \%$ osób doświadczało szumów usznych. Zaobserwowano znaczące różnice w przyjętych przez autorów metodach i narzędziach stosowanych do oceny uciążliwości szumów usznych. Rozbieżności dotyczyły także prezentowania pooperacyjnych wyników słuchowych. W nielicznych opublikowanych pracach postulowany jest brak związku pomiędzy pooperacyjną poprawą progów słyszenia a redukcją dokuczliwości szumów usznych. Jednakże w celu uzyskania porównywalnych wyników rekomendowane jest wykorzystywane w badaniach naukowych zaadaptowanych do języka ojczystego, rzetelnych oraz trafnych narzędzi.

Słowa kluczowe: szumy uszne $\bullet$ otoskleroza $\bullet$ niedosłuch $\bullet$ stapedotomia $\bullet$ chirurgia strzemiączka

\begin{abstract}
Tinnitus is a common symptom of otosclerosis, co-occurring with hearing loss. This paper presents a review of scientific literature on the prevalence of tinnitus and its distress among patients after stapes surgery. The review is based on electronic databases containing scientific articles: PubMed, the Cochrane Library and Web of Science. The objects of interests were reports on: the prevalence of tinnitus in otosclerosis, the impact of stapes surgery on postoperative changes in the perception of the condition, as well as types of methods and tools applied by authors to assess the investigated phenomena.

The literature review covered 13 articles. It was observed that $65-90 \%$ of patients in the group with otosclerosis experienced tinnitus. Furthermore, significant differences in methodologies and tools, which were used by respective authors to evaluate tinnitus distress were revealed. Discrepancies also occurred in the presentation of postoperative hearing results.

Very few works postulate the lack of a relationship between the postoperative improvement of hearing thresholds and the reduction of tinnitus distress. However, in order to obtain comparable results, it is recommended that reliable and valid tools adapted to a given native language should be used in scientific research.
\end{abstract}

Key words: tinnitus $\bullet$ otosclerosis $\bullet$ otosponigiosis $\bullet$ hearing loss $\bullet$ stapes surgery $\bullet$ stapedotomy $\bullet$ stapedectomy

Adres autora: Beata Dziendziel, Światowe Centrum Słuchu, ul. Mokra 17, Kajetany, 05-830 Nadarzyn, e-mail: b.dziendziel@ifps.org.pl
Zgłoszono: 20.02 .2017

Zaakceptowano: 29.04.2017 Opublikowano: 12.05.2017 


\section{Wstęp}

Otoskleroza charakteryzuje się występowaniem przewlekłego procesu patologicznego, prowadzącego do tworzenia się kostniny o charakterze kości gąbczastej i w efekcie do fiksacji płytki strzemiączka w okienku owalnym [1]. Do najczęściej wymienianych przyczyn otosklerozy zalicza się skłonność dziedziczną, infekcje wirusowe oraz różnego typu zaburzenia: immunologiczne, hormonalne, gospodarki mineralnej i aktywności enzymatycznej [2]. Szumy uszne (ang. tinnitus) stanowią, obok progresywnego ubytku słuchu, jeden $\mathrm{z}$ podstawowych symptomów rozwoju otosklerozy [3-6]. Są wrażeniem dźwiękowym słyszalnym w jednym lub obojgu uszach przy braku obecności zewnętrznego bodźca akustycznego w otoczeniu. Problem szumów usznych obserwowano również w grupie polskich dzieci [7] w wieku szkolnym - od 7 do 12 lat. Szacuje się, że może on dotyczyć nawet kilkunastu procent populacji pediatrycznej $[8,9]$. Podobną skalę występowania dolegliwości dla tej grupy wiekowej odnotowano na innych kontynentach $[10,11]$. Niewiele jednak wiadomo o szumach usznych występujących w przebiegu otosklerozy w wieku dziecięcym. Wymieniane hipotezy dotyczące powstawania szumów w otosklerozie zakładają, że nowo utworzona tkanka kostna poprzez swoje bogate unaczynienie sprzyja odczuwaniu szumów pulsujących [12]. Według Ismi i wsp. [6] wystąpienie szumów usznych może być konsekwencją redukcji drgań płynów ucha wewnętrznego lub obecności toksycznych bądź metabolicznych produktów ognisk otosklerozy. Badania przeprowadzone w grupie 330 pacjentów poddanych zabiegowi stapedotomii w Światowym Centrum Słuchu Instytutu Fizjologii i Patologii Słuchu wykazały, że przed operacją ponad $76 \%$ pacjentów uskarżało się na szumy uszne, a $20 \%$ na zawroty głowy [13]. Trudność w ocenie uciążliwości szumów usznych subiektywnych związana jest przede wszystkim z brakiem możliwości ich obiektywnego pomiaru [14]. Dodatkowy problem stanowi rozróżnienie, który z objawów - niedosłuch czy szumy uszne - ma bardziej negatywny wpływ na życie pacjenta.

Mimo coraz większej wiedzy na temat patomechanizmów odpowiedzialnych za szumy uszne występujące w przebiegu otosklerozy, wiele kwestii pozostaje wciąż niejasnych. Celem niniejszej pracy jest przegląd naukowych doniesień dotyczących częstości występowania szumów usznych i ich uciążliwości wśród pacjentów poddanych chirurgii strzemiączka, w szczególności:

- charakterystyki częstotliwościowej szumów usznych,

- danych socjodemograficznych,

- metod i narzędzi stosowanych do oceny uciążliwości szumów usznych,

- wyników operacyjnego leczenia otosklerozy z uwzględnieniem zmiany uciążliwości szumów usznych.

\section{Materiał i metody}

Przeglądu piśmiennictwa dokonano na podstawie elektronicznych zasobów artykułów naukowych, wyszukanych za pomoca baz: PubMed, The Cochrane Library oraz Web of Science w dniu 7 listopada 2016 roku. Strategia wyszukiwania zakładała użycie słów kluczowych: „otosclerosis and tinnitus”, „stapes surgery and tinnitus”, „stapedectomy and tinnitus”, „stapedotomy and tinnitus”. W celu uzyskania jak najbardziej aktualnych wyników, ramy czasowe ograniczono do lat 2000-2016. Liczba uzyskanych w ten sposób wyników wyniosła 247, z czego po usunięciu materiałów dotyczących tych samych grup chorych pozostało 211 pozycji. W pierwszej kolejności analizowane były tytuły oraz abstrakty artykułów. Kryteria wyłączające zakładały odrzucenie prac prezentujących wyłącznie technikę chirurgiczną zaproponowaną przez autorów lub pooperacyjne wyniki słuchowe pozbawione oceny uciążliwości szumów usznych. Z analizy wykluczono materiały konferencyjne. Ostatecznie do szczegółowego przeglądu literatury wybrano 13 publikacji w języku angielskim (tabela 1).

\section{Wyniki}

\section{Częstość występowania szumów usznych wśród pacjentów $\mathrm{Z}$ otosklerozą}

W badaniach Gristwood i Venables [15], którzy zaprezentowali największy materiał badawczy obejmujący 1014 pacjentów, chroniczne szumy uszne zostały przedoperacyjnie stwierdzone u $65 \%$ osób. Szumy diagnozowane były jako chroniczne wówczas, gdy trwały dłużej niż trzy miesiące bez jakichkolwiek symptomów ich ustąpienia. W badaniu nie wykazano związku pomiędzy czasem trwania niedosłuchu a spostrzeganą uciążliwością szumów. W kolejnym badaniu, przeprowadzonym przez Bagger-Sjöbäck i wsp.[16], wśród 135 osób kwalifikowanych do chirurgii strzemiączka $68 \%$ zgłaszało szumy uszne. Sobrinho i wsp. [17] oraz Rajati i wsp. [5] stwierdzili, że około $90 \%$ pacjentów doświadczyło przedoperacyjnie szumów usznych. Pośród 23 pacjentów w badaniach Lima i wsp. [18] $5 \mathrm{z}$ nich (21,7\%) zgłaszało szumy uszne trwające dłużej niż 10 lat. U kolejnych 5 osób szumy uszne trwały od 5 do 10 lat. Najliczniejszą grupę (56,5\%) stanowili chorzy, u których dokuczliwe objawy trwały krócej niż 5 lat. W materiale liczącym 40 chorych, zaprezentowanym przez Sparano i wsp. [4], czas trwania szumów usznych przed operacją wahał się pomiędzy rokiem a dwoma latami. W badanym piśmiennictwie tylko Ayache i wsp. [19] ocenili kolejność wystąpienia najczęściej zgłaszanych objawów otosklerozy. Przed operacją 47 pacjentów $(72,5 \%)$ obserwowało w pierwszej kolejności progresję niedosłuchu bez współistniejących szumów usznych, natomiast $14(21,5 \%)$ doświadczyło równoczesnego pogorszenia słuchu i wystąpienia szumów usznych. Jedynie 4 osoby (6\%) deklarowały pojawienie się szumów usznych jako pierwszego objawu otosklerozy. Ustalono także, że średni czas trwania choroby, liczony od momentu wystąpienia pierwszych objawów do momentu operacji, wyniósł 72 miesiące (zakres od 4 do 420 miesięcy).

\section{Charakterystyka częstotliwościowa szumów usznych}

W przestudiowanym piśmiennictwie znaleziono jedynie 4 prace zawierające opis charakterystyki częstotliwościowej szumów usznych występujących w przebiegu otosklerozy. W badaniu prowadzonym przez Ayache i wsp. [19] oceny częstotliwości szumów usznych dokonano z wykorzystaniem audiometru klinicznego. Zadaniem pacjenta było wskazanie tonu, który był najbardziej zbliżony do słyszanego przez niego dźwięku. W tych warunkach otrzymano następujące wyniki: 20 pacjentów $(41,7 \%)$ określiło przedoperacyjne szumy uszne jako wysokie tony, 11 pacjentów $(22,9 \%)$ jako średnie, a 13 pacjentów $(27,1 \%)$ jako niskie. 
Tabela 1. Informacje na temat autorów artykułów, roku publikacji oraz kraju, w którym zostały przeprowadzone badania włączone do przeglądu. Kolejność zgodna z rokiem publikacji

Table 1. Information about authors of articles, the year of publication and country in which studies included in the review were carried out (arranged with respect to the year of publication

\begin{tabular}{clcc}
\hline Lp. & \multicolumn{1}{c}{ Autorzy } & Rok publikacji & Kraj \\
\hline 1 & Gersdorff i wsp. & 2000 & Belgia \\
\hline 2 & Lima i wsp. & 2002 & Brazylia \\
\hline 3 & Ayache i wsp. & 2003 & Francja \\
\hline 4 & Gristwood i Venables & 2003 & Australia \\
\hline 5 & Szymański i wsp. & 2003 & Polska \\
\hline 6 & Sobrinho i wsp. & 2004 & Brazylia \\
\hline 7 & Sparano i wsp. & 2004 & USA \\
\hline 8 & Rajati i wsp. & 2012 & Irak \\
\hline 9 & Bast i wsp. & 2013 & Niemcy \\
\hline 10 & Chang i Cheung & 2014 & USA \\
\hline 11 & Bagger-Sjöbäck i wsp. & 2015 & Szwecja \\
\hline 12 & Dewyer i wsp. & 2015 & USA \\
\hline 13 & Ismi i wsp. & 2016 & Turcja \\
\hline
\end{tabular}

W przypadku 4 badanych (8,3\%) nie udało się określić częstotliwości. Na podstawie analizy statystycznej nie wykazano wpływu częstotliwości przedoperacyjnych szumów na zmianę w ich postrzeganiu po operacji, sugerując, że nie jest ona czynnikiem predykcyjnym uciążliwości. Podobne wnioski zaprezentowano w pracy Gersdorff i wsp. [20]. Po przebadaniu grupy 50 pacjentów stwierdzono, że częstotliwość i głośność słyszanych szumów usznych nie mają wartości prognostycznej w ocenie uciążliwości szumów usznych po operacyjnym leczeniu otosklerozy. Prawie $79 \%$ osób z przedoperacyjnymi wysokoczęstotliwościowymi szumami usznymi oraz $81 \%$ z szumami niskoczęstotliwościowymi zgłaszało zniknięcie bądź zmniejszenie uciążliwości szumów usznych po operacji. W badaniu przeprowadzonym przez Sobrinho i wsp. [17] informacje o częstotliwości słyszanych szumów usznych gromadzone były w oparciu o wybór jednego określenia z zestawu zaprezentowanych słów; wśród nich znajdowały się wysokie tony (szumy zbliżone do gwizdu) bądź dźwięki porównywalne do szumu białego (radio statyczne, wodospad). Pooperacyjna analiza wyników wykazała, że w grupie 11 pacjentów z przedoperacyjnymi wysokoczęstotliwościowymi szumami usznymi całkowite ustąpienie szumów usznych po operacji zgłaszało $3 \mathrm{z}$ nich, a u 6 wykazano zmniejszenie dolegliwości. Brak zmiany odnotowano u 2 chorych. W przypadku 8-osobowej grupy pacjentów z przedoperacyjnym szumem określonym jako szum biały, u 7 uzyskano całkowite ustąpienie objawu, a u jednej osoby znaczącą poprawę. Wykazano niską korelację pomiędzy częstotliwością przedoperacyjnych szumów a zmianą w ich spostrzeganiu po operacji. W badaniu Ismi i wsp. [6] ocena częstotliwości szumów usznych polegała na subiektywnym dopasowaniu słyszanych szumów usznych do jednego z dziewięciu audiometrycznych częstotliwości prezentowanych w słuchawkach (od 125 do $8000 \mathrm{~Hz}$ ). Następnie uzyskane wyniki podzielono na trzy grupy: szumy wysokoczęstotliwościowe $(4,6,8 \mathrm{kHz})-32$ pacjentów, szumy średnioczęstotliwościowe $(1,2,3 \mathrm{kHz})-4$ pacjentów oraz szumy niskoczęstotliwościowe $(125,250,500 \mathrm{~Hz})-$ 20 pacjentów. W odniesieniu do całej grupy 56 badanych, u 34 z nich $(60,7 \%)$ wykazano ustąpienie bądź redukcję dolegliwości po operacji. Dowiedziono silnego wpływu chirurgii strzemiączka na zmianę spostrzegania szumów usznych. Aż $90 \%$ pacjentów z niskoczęstotliwościowymi szumami usznymi deklarowało ustapienie bądź redukcję szumów, a pozostałych $10 \%$ zgłaszało brak zmiany. Natomiast $\mathrm{w}$ grupie pacjentów $\mathrm{z}$ wysokoczęstotliwościowymi szumami usznymi tylko 43,8\% zgłaszało ustąpienie dolegliwości bądź jej zmniejszone nasilenie.

\section{Dane socjodemograficzne}

Wiele doniesień naukowych wskazuje, że otoskleroza częściej występuje u kobiet $[4,5,15,17,19-23]$, będących zwłaszcza w okresach zmian hormonalnych [2]. We włączonej do przeglądu literaturze liczba udokumentowanych przypadków leczenia otosklerozy u kobiet wyniosła 937, a u mężczyzn 507, co potwierdza jej częstsze występowanie $\mathrm{w}$ tej grupie. Podsumowanie danych dotyczących wieku i płci badanych przedstawiono w tabeli 2 . Wyniki większości badań sugerują brak korelacji pomiędzy uciążliwością szumów usznych a płcią $[5,17,19]$. Na podstawie badania Gersdorff i wsp. [20] dowiedziono, że ponad dwa razy więcej kobiet niż mężczyzn odczuwało szumy uszne. Pomimo tej znaczącej różnicy nie wykazano istotnego wpływu płci na pooperacyjny przebieg dolegliwości. Sobrinho i wsp. [17] również nie wykazali związku pomiędzy płcią a pooperacyjną uciążliwością szumów usznych. Wyłoniono jednakże grupę 19 pacjentów uskarżających się na ich znaczną dokuczliwość (tzw. Severe Disabling Tinnitus, SDT). W grupie tej $84,2 \%$ stanowiły kobiety, a tylko $15,8 \%$ mężczyźni. Odmienne stanowisko zostało zaprezentowane przez Gristwood i wsp. [15], którzy wskazali na istotną statystycznie korelację pomiędzy płcią a obecnością przedoperacyjnych szumów usznych w przebiegu otosklerozy. Blisko 70\% spośród 663 kobiet 
Tabela 2. Zestawienie danych odnośnie do płci i wieku pacjentów prezentowanych w przeanalizowanym piśmiennictwie. Kolejność zgodna z rokiem publikacji

Table 2. Summary data on sex and age of patients presented in the analysed literature, arranged with respect to the year of publication

\begin{tabular}{lccccc}
\hline Autorzy i data publikacji & $\begin{array}{c}\text { Całkowity udział } \\
\text { pacjentów }\end{array}$ & $\begin{array}{c}\text { Liczba kobiet } \\
(\%)\end{array}$ & $\begin{array}{c}\text { Liczba mężczyzn } \\
\text { (\%) }\end{array}$ & $\begin{array}{c}\text { Średnia } \\
\text { wieku }\end{array}$ & $\begin{array}{c}\text { Zakres } \\
\text { wieku }\end{array}$ \\
\hline Gersdorff i wsp. 2000 & 50 & $34(68,0)$ & $16(32,0)$ & 50 & $32-72$ \\
\hline Ayache i wsp. 2003 & 62 & $41(66,1)$ & $21(33,9)$ & 46,3 & $26-70$ \\
\hline Gristwood i Venables 2003 & 1014 & $663(65,4)$ & $351(34,6)$ & brak & $13-89$ \\
\hline Sparano i wsp. 2004 & 40 & $25(62,5)$ & $15(37,5)$ & brak & $18-75$ \\
\hline Sobrinho i wsp. 2004 & 48 & $29(60,4)$ & $19(39,6)$ & 44,5 & $16-62$ \\
\hline Lima i wsp. 2005 & 23 & $11(47,8)$ & $12(52,2)$ & 37 & $25-54$ \\
\hline Rajati i wsp. 2012 & 29 & $20(69,0)$ & $9(31,0)$ & 39 & $13-65$ \\
\hline Chang i Cheung 2012 & 26 & $19(73,1)$ & $7(26,9)$ & 47,5 & brak \\
\hline Bast i wsp. 2013 & 34 & $21(61,8)$ & $13(38,2)$ & 42,9 & brak \\
\hline Dewyer i wsp. 2015 & 49 & $32(65,3)$ & $17(34,7)$ & 46 & brak \\
\hline Ismi i wsp. 2016 & 69 & $42(60,9)$ & $27(39,1)$ & 42 & $32-57$ \\
\hline
\end{tabular}

i około 56\% z 351 mężczyzn zgłaszało szumy uszne przed operacją. W artykule nie przedstawiono hipotez dotyczących możliwych przyczyn częstszego występowania szumów usznych wśród kobiet.

W większości badań nie zaobserwowano również wpływu wieku na uciążliwość szumów usznych $[5,15,17,19]$, jednakże kryteria włączenia do badania zakładały przeważnie udział wyłącznie pacjentów dorosłych. Tylko Sobrinho i wsp. [17] oraz Rajati i wsp. [5] do badania włączyli także osoby poniżej 18 roku życia. Na podstawie analizy statystycznej nie udało się powiązać wieku z częstością występowania szumów usznych towarzyszących otosklerozie. Odmienny pogląd zaprezentowano w badaniu Bagger i wsp. [16], którzy podjęli próbę oceny wpływu wysokoczęstotliwościowego ubytku słuchu na ich pooperacyjną uciążliwość. Uzyskane wyniki wykazały, że wiek był silnym predykatorem zmiany spostrzegania dolegliwości u tych pacjentów, u których na skutek operacji doszło do podwyższenia progu przewodnictwa powietrznego w zakresie wysokich częstotliwości. Wysunięto wniosek, że u pacjenta w młodym wieku, mimo osłabienia słyszenia w zakresie wysokich częstotliwości, istnieje większe prawdopodobieństwo ustąpienia bądź zmniejszenia uciążliwości szumów usznych po przeprowadzonej chirurgii strzemiączka. Odwrotna sytuacja ma miejsce u osób starszych, u których istnieje większe prawdopodobieństwo braku zmiany lub nasilenia się szumów usznych w wyniku nabytego w czasie operacji ubytku słuchu w zakresie wysokich częstotliwości.

\section{Metody i narzędzia stosowane do oceny szumów usznych}

Przegląd literatury wykazał stosowanie przez badaczy różnych metod i technik pomiaru uciążliwości szumów usznych towarzyszących otosklerozie. W badaniu Ayache i wsp. [19] do oceny szumów usznych posłużono się własnym narzędziem, składającym się z zestawu pytań dotyczących pierwszych klinicznych symptomów otosklerozy, czasu wystąpienia, intensywności oraz dokuczliwości szumów usznych. Charakterystyka szumów usznych polegała na wskazaniu przez pacjenta, na podstawie listy 20 słów, dźwięku, który najbardziej zbliżony był do odczuwanej dolegliwości. Ponadto pacjenci na podstawie własnych wrażeń określali ich uciążliwość jako niewielką, dokuczliwą, irytującą bądź nieznośną (odpowiednio slightly bothersome, bothersome, irritating, unbearable). Stosownie do uzyskanych wyników, chorych podzielono na 3 grupy pod kątem strategii radzenia sobie z szumami usznymi. Pierwszą grupę stanowiło 17 osób (26,1\%), które nie odczuwały szumów usznych, drugą - 32 pacjentów (49,2\%), którzy potrafili radzić sobie z szumami usznymi. Ostatnią grupę stanowiło 16 chorych $(24,6 \%)$, którzy skarżyli się na ich znaczną uciążliwość. Inną metodologię prezentowano w pracy Sparano i wsp. [4]. W badaniu wykorzystano narzędzie Klockhoff and Lindbloom Classification System for Distingushing Levels of Tinnitus Distress (w skrócie klasyfikacja K/L) z 1967 roku, która stworzona została $\mathrm{z}$ myślą o terapeutycznym leczeniu pacjentów z chorobą Ménière’a. Metoda klasyfikacji K/L oparta jest na stosowaniu 7-stopniowej skali w odniesieniu do występowania szumów usznych i intensywności w ich spostrzeganiu. W badaniu Rajati i wsp. [5] w celu oceny dolegliwości powołano się na metodę Newmana z 1996 roku. Na podstawie przedoperacyjnych wyników kwestionariuszowych wypełnionych przez uczestników badania dokonano podziału na pięć stopni uciążliwości szumów usznych. $\mathrm{Na}$ I stopień klasyfikowało się 2 pacjentów, II stopień - 4 pacjentów, III stopień - 11 pacjentów, IV stopień - 9 pacjentów. Żaden uczestnik badania nie osiągnął V stopnia uciążliwości szumów usznych. Autorzy przyjęli, że IV i V stopień oznacza znaczną uciążliwość szumów usznych, określaną jako Severe Disabling Tinnitus - SDT.

Pośród przestudiowanego piśmiennictwa, w 4 pracach zaobserwowano stosowanie Wizualnej Skali Analogowej (ang. 
Tabela 3. Wpływ chirurgii strzemiączka na zmianę w spostrzeganiu szumów usznych pacjentów prezentowanych w przeanalizowanym piśmiennictwie. Kolejność zgodna z rokiem publikacji

Table 3. The impact of stapes surgery on a change in the perception of tinnitus among patients presented in the analysed literature (arranged with respect to the year of publication

\begin{tabular}{|c|c|c|c|c|c|c|c|c|}
\hline \multirow{2}{*}{$\begin{array}{l}\text { Autorzy i data } \\
\text { publikacji }\end{array}$} & \multirow{2}{*}{$\begin{array}{c}\text { Liczba } \\
\text { osób } \\
\text { badanych }\end{array}$} & \multirow{2}{*}{$\begin{array}{l}\text { Liczba osób } \\
\text { z szumami } \\
\text { usznymi (\%) }\end{array}$} & \multirow{2}{*}{$\begin{array}{l}\text { Okres } \\
\text { obserwacji } \\
\text { (mc) }\end{array}$} & \multirow{2}{*}{$\begin{array}{l}\text { Metoda oceny } \\
\text { zmiany szumów } \\
\text { usznych }\end{array}$} & \multicolumn{4}{|c|}{$\begin{array}{c}\text { Pooperacyjna ocena dokuczliwości szumów } \\
\text { usznych (\%) }\end{array}$} \\
\hline & & & & & ustąpienie & poprawa & bez zmian & pogorszenie \\
\hline $\begin{array}{l}\text { Gersdorff i wsp. } \\
2000\end{array}$ & 50 & $n / d^{1}$ & 12 & Brak informacji & 64,0 & 16,0 & 14,0 & 6,0 \\
\hline $\begin{array}{l}\text { Ayache i wsp. } \\
2003\end{array}$ & 62 & $48(77,4)$ & 1 & Analiza statystyczna & 56,3 & 27,1 & 12,5 & 4,1 \\
\hline $\begin{array}{l}\text { Szymański i wsp. } \\
2003\end{array}$ & 207 & $149(72,0)$ & $12-228$ & Analiza statystyczna & 73,0 & 17,0 & 10,0 & 0 \\
\hline $\begin{array}{l}\text { Sparano i wsp. } \\
2004\end{array}$ & 40 & $n / d^{1}$ & brak informacji & Klasyfikacja K/L² & \multicolumn{2}{|c|}{85,0} & 12,5 & 2,5 \\
\hline $\begin{array}{l}\text { Sobrinho i wsp. } \\
2004\end{array}$ & 48 & $44(91,7)$ & $4-14$ i $14-48$ & Skala VAS ${ }^{3}$ & 63,3 & 27,6 & 9,1 & 0 \\
\hline Lima i wsp. 2005 & 23 & $n / d^{1}$ & $3-12$ & Skala VAS ${ }^{3}$ & 39,1 & 56,5 & 4,4 & 0 \\
\hline Rajati i wsp. 2012 & 29 & $26(89,7)$ & 1 & Analiza statystyczna & 55,2 & 27,6 & 17,2 & 0 \\
\hline Ismi i wsp. 2016 & 69 & $56(81,2)$ & $\leq 12$ & Analiza statystyczna & 50,0 & 10,7 & 39,3 & 0 \\
\hline
\end{tabular}

${ }_{1}^{1} \mathrm{n} / \mathrm{d}$ - oznacza, że kryterium włączenia zakładało udział w badaniu wyłącznie pacjentów dotkniętych szumami usznymi

${ }^{2}$ klasyfikacja K/L - Klockhoff and Lindblom Classification System for Distinguishing Levels of Tinnitus Distress

${ }^{3}$ skala VAS - Wizualna Skala Analogowa

Visual Analog Scale, VAS) do oceny dokuczliwości szumów usznych. Przyjęta przez autorów dolna granica punktacji najczęściej odpowiadała bardzo łagodnemu nasileniu dolegliwości, a górna - nieznośnemu [16-18]. Inne podejście, zakładajace wykorzystanie skali VAS, zaprezentowano w pracy Dewyer i wsp. [23]. Jedenastostopniową skalę VAS zastosowano mianowicie do oceny głośności szumów usznych, gdzie 0 punktów korespondowało z brakiem słyszenia szumów usznych, 5 oznaczało głośność zbliżoną do poziomu mowy, a 10 - głośność porównywalną do silnika odrzutowca. Jednakże celem badania była nie tyle ocena głośności, co wyznaczenie korelacji pomiędzy głośnością szumów usznych i ich uciążliwością mierzoną kwestionariuszem Tinnitus Functional Index (TFI), w którym za klinicznie istotną zmianę (ang. minimal important clinical difference, MCID) przyjęto 13-punktową redukcję wyniku.

Kolejnym narzędziem służącym ocenie dolegliwości był kwestionariusz Tinnitus Questionnaire (TQ) stworzony przez Goebel and Hiller, zastosowany w badaniu Bast i wsp. [22]. Celem badania było ustalenie szerokiego spektrum dolegliwości psychologicznych związanych z szumami usznymi w celu złagodzenia ich dolegliwości. W pracy przyjęto, że wyniki od 0 do 46 punktów świadczą o „kompensacji” szumów usznych, a wyniki powyżej 47 punktów o szumach „nieskompensowanych”.

\section{Wpływ chirurgii strzemiączka na uciążliwość szumów usznych}

O ile istnieją liczne doniesienia na temat rezultatów słuchowych operacyjnego leczenia otosklerozy, o tyle niewiele publikacji naukowych donosi o zmianach w zakresie odczuwanych szumów usznych po przeprowadzonej procedurze chirurgicznej. Pooperacyjne wyniki chirurgii strzemiączka i ich wpływ na zmianę w spostrzeganiu szumów usznych ujęto w tabeli 3. Dla czytelności danych przedstawiono wyniki tylko tych prac, na podstawie których możliwe było porównanie pooperacyjnych wyników zmian w spostrzeganiu szumów usznych.

Ismi i wsp. [6] podają, że $81,1 \%$ pacjentów chorujących na otosklerozę towarzyszyły szumy uszne. W grupie 56 chorych uzyskano zamknięcie rezerwy ślimakowej (ang. Air-Bone Gap, ABG) dla 78,6\% operowanych uszu, zmniejszenie rezerwy ślimakowej mieszczącej się w przedziale 10-20 dB uzyskano dla 16\%, a u 5,4\% uszu wielkość rezerwy ślimakowej przekraczała $20 \mathrm{~dB}$. Wyniki pooperacyjnych zmian percepcji szumów usznych przedstawiono w ramach 4 grup: I - całkowite ustąpienie szumów usznych, II - zmniejszenie dolegliwości, III - brak zmian, IV - nasilenie szumów usznych. Całkowite wyniki wskazują, że 60,7\% pacjentów odniosło korzyści pooperacyjne w postaci ustąpienia bądź zmniejszenia dolegliwości, kwalifikując się do grupy I lub II, natomiast u 22 pacjentów $(39,3 \%)$ szumy uszne nie uległy zmianie. Ustąpienie szumów usznych po operacji nie miało związku z pooperacyjnym zamknięciem rezerwy ślimakowej. Ponadto na podstawie analizy statystycznej nie wykazano korelacji pomiędzy zmniejszeniem ABG a wysokoczęstotliwościowymi szumami usznymi, w przeciwieństwie do niskoczęstotliwościowych szumów usznych - w przypadku ich obecności, po udanej operacji zamknięcia rezerwy ślimakowej, istniało większe prawdopodobieństwo ich zniknięcia. W wynikach prezentowanych przez Szymańskiego i wsp. [3] 82\% pacjentów uzyskało pooperacyjnie średnią wartość $\mathrm{ABG}$ na poziomie nie większym niż $15 \mathrm{~dB}$, a tylko u 9\% ABG przekraczało 20 dB. Analiza statystyczna 
wykazała, że w $73 \%$ operowanych uszu odnotowano zniknięcie szumów usznych. Zmniejszoną ich dokuczliwość obserwowano w $17 \%$, a $10 \%$ chorych zgłaszało brak zmiany. Pomimo dobrych rezultatów stwierdzono, że pooperacyjna poprawa słyszenia nie może stanowić czynnika predykcyjnego spostrzegania uciążliwości szumów usznych po operacji. Potwierdzeniem tej tezy jest przykład 5 chorych, u których szumy uszne ustąpiły po operacji mimo braku poprawy słuchu (średnia $\mathrm{ABG}=30 \mathrm{~dB}$ ). Kolejnymi autorami postulującymi brak wpływu poprawy słuchu po operacji na szumy uszne są Gersdorff i wsp. [20]. W ich pracy ocenę wielkości ABG oparto na wytycznych American Academy of Otolaryngology - Head and Neck Surgery (AAO-HNS), jakkolwiek wyniki słuchowe przedstawiono w postaci wartości procentowych. Po operacji pogorszenie szumów usznych zgłaszało 3 pacjentów, u których zamknięcie rezerwy ślimakowej oscylowało na poziomie $76 \%$. Pacjenci, którzy zgłaszali brak zmiany w spostrzeganiu szumów usznych, osiągnęli przeciętne zamknięcie ABG na poziomie $70 \%$. Istotne znaczenie ma fakt, że najkorzystniejszy efekt zamknięcia ABG (średnio 90\%) uzyskano w grupie pacjentów, którzy zgłaszali zniknięcie szumów usznych. Ayache i wsp. [19] również nie wykazali wpływu pooperacyjnych progów słyszenia na obecność szumów w grupie 16 chorych ze znaczną uciążliwością szumów usznych (SDT), którzy przedoperacyjne szumy uszne spostrzegali jako uciążliwe, irytujące lub nie do zniesienia. W badaniach Gristwood i wsp. [15] wszystkich badanych podzielono na 4 grupy pod względem wielkości rezerwy ślimakowej, a następnie porównywano występowanie szumów w każdej z nich. Wraz ze wzrostem wielkości rezerwy ślimakowej wzrastała liczba pacjentów z szumami, ale zjawisko to występowało tylko w trzech pierwszych grupach. W czwartej grupie $\mathrm{z}$ największą rezerwą ślimakową (w zakresie 41,26-65,50 dB) liczba chorych z szumami usznymi zmniejszyła się.

Sparano i wsp. [4] w ocenie pooperacyjnej zmiany szumów usznych posłużyli się klasyfikacją K/L, a uzyskane wyniki porównywali $\mathrm{z}$ wynikami audiometrycznych badań słuchu. Ocena za pomocą K/L przeprowadzona w 40-osobowej grupie pacjentów wykazała, że u 34 pacjentów (85\%) zmniejszyło się nasilenie szumów usznych po operacji. Pozostałych 5 pacjentów (12,5\%) nie odczuło zmiany, a tylko 1 chory $(2,5 \%)$ zgłaszał pogorszenie. Pooperacyjny wynik audiometrii tonalnej dostępny był dla 18 pacjentów. Na podstawie przyjętej klasyfikacji K/L autorzy wnioskowali, że pooperacyjna rezerwa ślimakowa była znacząco mniejsza ('średnie $\mathrm{ABG}=9,6 \mathrm{~dB}$ ) w grupie pacjentów, u których zmniejszyła się dokuczliwość szumów usznych $(\mathrm{n}=16)$, w porównaniu $z$ grupą pacjentów $(n=2)$, którzy zgłaszali brak zmiany $w$ ich spostrzeganiu (średnie $A B G=23,8$ dB). W badaniu przeprowadzonym przez Lima i wsp. [18] uciążliwość szumów usznych zarówno przed operacją, jak i po zabiegu oceniono na podstawie wizualnej skali analogowej. Ustalono, że 22 z 23 pacjentów zgłaszało zmniejszoną dokuczliwość szumów usznych po operacji. Na podstawie przedoperacyjnych wyników audiometrycznych oszacowano średnią wielkość rezerwy ślimakowej wynoszącą 34,13 dB. Po operacji całkowite zamknięcie rezerwy ślimakowej uzyskano w 17 operowanych uszach (73,9\%). Analiza statystyczna wykazała niską korelację pomiędzy zmniejszeniem ABG a zmianą uciążliwości szumów. Podobne wnioski uzyskano w badaniu Sobrinho i wsp. [17].
Odmienne podejście badawcze przedstawiono w pracy Bagger i wsp. [16], którzy analizowali wpływ głębokości niedosłuchu wysokoczęstotliwościowego na pooperacyjną zmianę uciążliwości szumów usznych. Stwierdzono 32-proc. prawdopodobieństwo nasilenia szumów usznych i tylko $21 \%$ szansy na ich zmniejszenie po operacji w grupie pacjentów ze znacznym, wysokoczęstotliwościowym ubytkiem słuchu. Jednocześnie pacjenci, którzy wykazywali niższe wartości progu słyszenia w zakresie wysokich częstotliwości, po operacji mieli o 56\% więcej szans na zmniejszenie uciążliwości szumów i tylko $9 \%$ ryzyka nasilenia objawu. Bast i wsp. [22] dokonali oceny pooperacyjnych szumów, wykorzystując wyniki kwestionariusza TQ. Na podstawie wyników przedoperacyjnych podzielono pacjentów na dwie grupy: pierwszą stanowiły osoby ze „skompensowanymi” szumami usznymi (wyniki w przedziale 0-46 punktów), drugą - $\mathrm{z}$ „nieskompensowanymi” (przedział 47-84). Stwierdzono, że w grupie pacjentów (n=23) ze „skompensowanymi” przedoperacyjnymi szumami usznymi, po operacji uzyskano korzystny rezultat w postaci zmniejszenia uciążliwości dolegliwości. Podobnej zależności nie obserwowano $\mathrm{w}$ grupie pacjentów $(\mathrm{n}=5) \mathrm{z}$ „nieskompensowanymi” szumami usznymi.

\section{Pooperacyjne ryzyko wystąpienia szumów usznych}

Ryzyko wystąpienia szumów usznych w grupie pacjentów, którzy ich nie doświadczyli przed operacją, czy też wystąpienia pooperacyjnego nasilenia uciążliwości nie było szczegółowo analizowane przez autorów. W badaniu Ayache i wsp. [19] nie zaobserwowano pojawienia się szumów usznych u pacjentów, którzy wcześniej ich nie zgłaszali, a nasilenie objawu wystąpiło u jedynie $4,2 \%$ badanych. Bast i wsp. [22] stwierdzili pooperacyjne wystąpienie szumów usznych jedynie u 1 chorego, u którego ustąpiły one w ciągu 6 tygodni. Podobne wyniki otrzymano w pracy Rajati i wsp. [5], gdzie szumy uszne wystąpiły na krótko u 2 z 3 pacjentów, którzy przed operacją ich nie zgłaszali, a następnie ustąpiły po miesiącu. Chang i wsp. [21] stwierdzili, że pacjenci z niewielkimi dolegliwościami szumowymi $(\mathrm{n}=26)$ mieli 10-proc. ryzyko wystąpienia epizodu nasilenia objawów po operacji. W ciągu 6 miesięcy od zabiegu obserwowano jednak ich zanik. W badaniu prowadzonym przez Bagger-Sjöbäck i wsp. [16] na grupie 133 pacjentów poddanych operacyjnemu leczeniu otosklerozy wykazano, że 23\% chorych, którzy nie doświadczyli szumów usznych przed operacją, zgłaszało ich obecność właściwie natychmiast po zabiegu. W ciągu 12-miesięcznej obserwacji występowanie tego zjawiska zmniejszyło się do $19 \%$.

\section{Dyskusja}

Na podstawie przestudiowanego piśmiennictwa stwierdzono, że od $65 \%$ do ponad $90 \%$ pacjentów dotkniętych otosklerozą doświadczało szumów usznych. W badaniach prowadzonych przez Lima i wsp. [18] oraz Sparano i wsp. [4] obserwowano różne kryterium podziału czasu trwania szumów usznych przed operacją. Informacje na temat częstości odczuwania szumów usznych, określanych jako stałe, okazjonalne czy rzadkie, gromadzono wyłącznie w pracy Sobrinho i wsp. [17], ale autorzy nie przedstawili uzyskanych wyników. W poszczególnych pracach na podstawie kryteriów włączających założono, że ucho kwalifikowane 
do zabiegu nie mogło być wcześniej operowane $[4,5,18,19]$, podczas gdy w innych prezentowano bardziej selektywne podejście i włączono tylko pacjentów z szumami usznymi $[4,18,20]$. Tymczasem w badaniach Ayache i wsp. [19] oraz Ismi i wsp. [6] uwzględniano dodatkowo wielkość przedoperacyjnej rezerwy ślimakowej. Rozbieżności w zakresie oceny rozpowszechnienia szumów usznych w grupie pacjentów z rozpoznaną otosklerozą skutkowały brakiem możliwości łączenia i interpretacji wyników studiowanego piśmiennictwa.

Analizę charakterystyki częstotliwości szumów występujących w otosklerozie przeprowadzono w 4 pracach. Gersdorff i wsp. [20] wysokość i głośność przedoperacyjnych szumów usznych zbadali, opierając się wyłącznie na samoocenie pacjentów. Uzyskano niską korelację pomiędzy częstotliwością oraz zmianą $\mathrm{w}$ ich postrzeganiu po operacji. Podobne wnioski wysunięto w pracy Sobrinho i wsp. [11]. Wyniki wcześniejszych prac odbiegają od tych uzyskanych przez Ismi i wsp. [6]. Autorzy podkreślają wyraźne ustąpienie szumów bądź ich redukcję po operacji w grupie pacjentów z niskoczęstotliwościowymi szumami, w przeciwieństwie do szumów wysokoczęstotliwościowych. O możliwości redukcji niskoczęstotliwościowych szumów, a nawet ich ustąpienia, po chirurgii strzemiączka pisano w pracy Causse i wsp. [24]. Zaproponowano wyjaśnienie, zgodnie z którym otoskleroza i następcza fiksacja strzemiączka w okienku owalnym prowadzi do słabszych wibracji płynów ucha wewnętrznego głównie w części szczytowej ślimaka, przyczyniając się tym samym do wystąpienia niskoczęstotliwościowych szumów usznych oraz współistniejącego niedosłuchu. W przypadku chirurgii strzemiączka, której celem jest poprawa ruchomości zastąpionego protezką strzemiączka, dochodzi do poprawy wibracji płynów ucha wewnętrznego, a w efekcie do ustąpienia dolegliwości.

Na podstawie przestudiowanej literatury przedmiotu wykazano po raz kolejny, że otoskleroza jest przypadłością częściej występującą u kobiet niż mężczyzn. Liczba kobiet objętych badaniem była blisko dwukrotnie większa niż mężczyzn. Pomimo znaczącego udziału kobiet z rozpoznaną i leczoną operacyjnie otosklerozą, większość autorów wnioskowała o braku wpływu płci na wystąpienie oraz dokuczliwość szumów usznych zarówno przed operacją, jak i po zabiegu $[5,17,19,20]$. Odmiennego zdania byli Gristwood i wsp. [15], którzy zaprezentowali największy materiał badawczy (1014 chorych), wykazując statystyczną istotność udziału kobiet cierpiących z powodu szumów usznych w przebiegu otosklerozy.

W większości badań nie wykazano także wpływu wieku na uciążliwość szumów usznych $[5,15,17,19]$.

Liczne rozbieżności obserwowano w przypadku wyboru metod oceny dokuczliwości szumów usznych przed operacją i po niej. W badaniach Ayache i wsp. [19] oraz Gersdorff i wsp. [20] posłużono się autorskim zestawem pytań. Nie zaprezentowano jednakże szczegółowej budowy, zawartości i sposobu oceny oraz interpretacji wyników pacjenta. Odmienną metodę oceny dokuczliwości szumów usznych zaprezentowano w badaniu Sparano i wsp. [4], stosując klasyfikację K/L. W badaniu Rajati i wsp. [5] powoływano się na 5-stopniową skalę Newmana z 1996 roku. Autorzy nie sprecyzowali jednak, że przyjęta metoda dotyczyła kwestionariusza Tinnitus Handicap Inventory (THI). W pracy nie wyjaśniono także znaczenia przyjętych przez badaczy 5 skal uciążliwości szumów usznych, których wyniki przedstawiono wyłącznie dla okresu przedoperacyjnego. W rzeczywistości, w artykule źródłowym, na który powołali się sami autorzy, nie zaproponowano podziału wyników kwestionariusza THI na stopnie uciążliwości ani kryteria kwalifikacji do poszczególnych kategorii. Dopiero dwa lata później Newman i wsp. [25] opracowali proponowane kategorie uciążliwości szumów usznych, które zostały rozszerzone i udoskonalone w 2001 roku przez McCombe’a i wsp. [26]. W kolejnych czterech pozycjach literaturowych [16-18,23] do oceny uciążliwości szumów usznych wykorzystano Wizualną Skalę Analogową (VAS). W pracy Bagger i wsp. [16] metodą tą dodatkowo zbadano poziom satysfakcji pacjenta po operacji. Co ciekawe, na podstawie regresji logistycznej stwierdzono, że prawdopodobieństwo satysfakcjonującego wyniku (>7 pkt) wynosi $81 \%$ w grupie pacjentów, u których obserwowano zmniejszenie dolegliwości, oraz tylko $43 \% \mathrm{w}$ grupie pacjentów $\mathrm{z}$ nasilonymi szumami usznymi. Odmienne podejście do tematu szumów usznych u pacjentów $\mathrm{z}$ rozpoznaną otosklerozą zaprezentowano w pracy Dewyer i wsp. [23]. Celem badania było wyznaczenie związku między zmianą głośności szumów usznych (pomiar skalą VAS) i ich dokuczliwością (pomiar kwestionariuszem TFI). Tymczasem w badaniu prowadzonym przez Bast i wsp. [22] do oceny uciążliwości szumów usznych zastosowano kwestionariusz Tinnitus Questionnaire.

Z uwagi na odmienne kryteria oceny dokuczliwości szumów usznych przyjęte przez autorów, nie można wyciągnąć obiektywnych wniosków na temat najlepszego schematu postępowania. Prezentowane badania naukowe nie zawsze były poprawne metodologicznie, co wpłynęło na niską ocenę ich rzetelności i wiarygodności.

Oceniając wyniki słuchowe operacyjnego leczenia otosklerozy, autorzy $[3,6,19,20,23]$ najczęściej powoływali się na wytyczne Amerykańskiej Akademii Otolaryngologii, Chirurgii Głowy i Szyi (American Academy of Otolaryngology - Head and Neck Surgery, AAO - HNS) [27]. Obserwowano jednak rozbieżności w sposobie prezentacji rezultatów. W pracy Gersdorff i wsp. [20] wielkość rezerwy ślimakowej (ABG) przedstawiono w postaci wartości procentowej i pomimo opisania sposobu jej przeliczania, otrzymane dane trudno łączyć i porównać z wynikami uzyskanymi przez pozostałych badaczy. W badaniu Sobrinho i wsp. [17] nie opisano metodyki pomiaru oraz nie powoływano się na źródło informujące o przyjętym sposobie wyznaczania wielkości rezerwy ślimakowej. W pracy Sparanio i wsp. [4] na podstawie przyjętej klasyfikacji K/L stwierdzono, że pooperacyjna rezerwa ślimakowa była znacząco mniejsza w grupie 16 chorych, u których zmniejszyła się dokuczliwość szumów usznych, w porównaniu z 2 pacjentami z mniejszą poprawą słuchu, którzy zgłaszali brak zmiany w spostrzeganiu dolegliwości. Wnioski poparte wynikami zaledwie dwóch pacjentów wydają się niewiarygodne.

Autorzy poszczególnych badań byli zgodni co do braku związku pomiędzy pooperacyjną poprawą słuchu a redukcją dokuczliwości szumów usznych [3,6,18-20]. Badania jednak różniły się metodologią, m.in. sposobem oceny dokuczliwości szumów usznych oraz zastosowanymi 
testami statystycznymi. Także przyjęcie przez badaczy różnych okresów obserwacyjnych i ich przedziałów czasowych spowodowało, że nie można było wysunąć silnych argumentów przy wyborze prawidłowych ram czasowych.

Ponadto zaobserwowano istnienie niewielkiego ryzyka nasilenia się szumów usznych po chirurgii strzemiączka bądź wystąpienia dolegliwości u pacjentów, którzy wcześniej ich nie doświadczyli. Najczęściej miały one charakter przemijający. Z uwagi na fakt, że dowody poparte były mało licznymi grupami pacjentów, nie można na tej podstawie wyciągnąć jednoznacznych i obiektywnych wniosków.

\section{Wnioski}

Istnieje niewiele publikacji naukowych na temat rozpowszechnienia i oceny dokuczliwości szumów usznych u pacjentów poddanych chirurgii strzemiączka. Obecnie nadal istnieje tendencja do prezentowania wyłącznie pooperacyjnych wyników słuchowych.

W nielicznych opublikowanych pracach postulowany jest brak związku pomiędzy pooperacyjną poprawą progów słyszenia a redukcją dokuczliwości szumów usznych. Jednakże uzyskane wnioski formułowane są przeważnie na podstawie danych pochodzących od mało licznych grup pacjentów. Zaobserwowane rozbieżności metodologiczne uniemożliwiają przeprowadzenie wiarygodnych metaanaliz dostępnego materiału. W celu uzyskania porównywalnych wyników rekomendowane jest przede wszystkim wykorzystywanie w badaniach naukowych zaadoptowanych do języka ojczystego, rzetelnych, trafnych i wystandaryzowanych narzędzi.

\section{Piśmiennictwo:}

1. Skarżyński H, Mrówka M, Młotkowska-Klimek P, Sitarz L, Wysocki J, Skarżyńska B. Stapedotomia w zaawansowanej otosklerozie i tympanosklerozie. Audiofonologia, 2003; XXIV.

2. Śliwińska-Kowalska M. Audiologia kliniczna. Łódź: MEDITON Oficyna Wydawnicza, 2005; 237-48.

3. Szymański M, Gołabek W, Mills R. Effect of stapedectomy on subjective tinnitus. J Laryngol Otol, 2003; 117(4): 261-64.

4. Sparano A, Leonetti JP, Marzo S, Kim H. Effects of stapedectomy on tinnitus in patients with otosclerosis. Int Tinnitus J, 2004; 10(1): 73-77.

5. Rajati M, Poursadegh M, Bakhshaee M, Abbasi A, Shahabi A. Outcome of stapes surgery for tinnitus recovery in otosclerosis. Int Tinnitus J, 2012; 17(1): 42-46.

6. Ismi O, Erdogan O, Yesilova M, Ozcan C, Ovla D, Gorur K Does stapes surgery improve tinnitus in patients with otosclerosis? Braz J Otorhinolaryngol, 2016.

7. Skarzynski PH, Kochanek K, Skarzynski H. Hearing screening program in school-age children in Western Poland. J Int Adv Otol, 2011; 7(2): 194-200.

8. Raj-Koziak D, Skarżynski PH, Skarżyński H. Ocena częstości występowania oraz charakterystyka szumów usznych istotnych klinicznie wśród 12-latków. Now Audiofonol, 2016; 5(Suplement 1): 9-10.

9. Raj-Koziak D, Skarzynski PH, Kochanek K. i wsp. The prevalence of tinnitus in 7 years old children in Poland. $10^{\text {th }}$ ESPCI Athens, Medimond, 2011: 269-72.

10. Skarzynski PH, Pilka A, Ludwikowski M. Comparison of the frequency of positive hearing screening outcomes in schoolchildren from Poland and other countries of Europe, Central Asia, and Africa. J Hear Sci, 2015; 4(4): 51-58.

11. Skarzyński PH, Świerniak W, Piłka A, Skarżynska MB, Włodarczyk AW, Kholmatov D i wsp. A hearing screening program for children in primary schools in Tajikistan: A telemedicine model. Med Sci Monit, 2016; 22: 2424-30.

12. Bartnik G. Szumy uszne i nadwrażliwość słuchowa. Warszawa: Instytut Fizjologii i Patologii Słuchu, 2010, s. 61-62.

13. Skarżynski PH, Król B, Mrówka M, Porowski M, Skarżyński H. Ocena korzyści z zastosowania protezek teflonowych w leczeniu otosklerozy. Now Audiofonol, 2016; 5(Suplement 1): 58-59.

14. Raj-Koziak D. Występowanie szumów usznych u dorosłych - przegląd piśmiennictwa. Now Audiofonol, 2016; 5(2): 24-29.
15. Gristwood RE, Venables WN. Otosclerosis and chronic tinnitus. Ann Otol Rhinol Laryngol, 2003; 112(5): 398.

16. Bagger-Sjöbäck D, Strömbäck K, Hultcrantz M, Papatziamos G, Smeds H, Danckwardt-Lillieström N i wsp. High-frequency hearing, tinnitus, and patient satisfaction with stapedotomy: A randomized prospective study. Sci Rep, 2015; 5: 13341.

17. Sobrinho PG, Oliveira CA, Venosa AR. Long-term follow-up of tinnitus in patients with otosclerosis after stapes surgery. Int Tinnitus J, 2004; 10(2): 197-201.

18. Lima A da S, Sanchez TG, Marcondes R, Bento RF. The effect of stapedotomy on tinnitus in patients with otospongiosis. Ear Nose Throat J, 2005; 84(7): 412-14.

19. Ayache D, Earally F, Elbaz P. Characteristics and postoperative course of tinnitus in otosclerosis. Otol Neurotol, 2003; 24(1): $48-51$.

20. Gersdorff M, Nouwen J, Gilain C, Decat M, Betsch C. Tinnitus and otosclerosis. Eur Arch Oto-Rhino-Laryngol, 2000; 257(6): 314-16.

21. Chang CYJ, Cheung SW. Tinnitus modulation by stapedectomy. Otol Neurotol, 2014; 35(6): 1065-69.

22. Bast F, Mazurek B, Schrom T. Effect of stapedotomy on pre-operative tinnitus and its psychosomatic burden. Auris Nasus Larynx, 2013; 40(6): 530-33.

23. Dewyer NA, Kiringoda R, Kram YA, Chang JL, Chang CYJ, Cheung SW. Stapedectomy effects on tinnitus: relationship of change in loudness to change in severity. Otolaryngol - Head Neck Surg, 2015; 153(6): 1019-23.

24. Causse J-B, Vincent R. Surgery and tinnitus for otosclerotic patients. Int Tinnitus J, 1996; 2: 123-27.

25. Newman CW, Sandridge SA, Jacobson GP. Psychometric adequacy of the Tinnitus Handicap Inventory (THI) for evaluating treatment outcome. J Am Acad Audiol, 1998; 9(2): 153-60.

26. McCombe A, Baguley D, Coles R, McKenna L, McKinney C, Windle-Taylor P. Guidelines for the grading of tinnitus severity: the results of a working group commissioned by the British Association of Otolaryngologists, Head and Neck Surgeons, 1999. Clin Otolaryngol Allied Sci, 2001; 26(5): 388-93.

27. Monsell E, Balkany T, Gates G, Goldenberg R, Meyerhoff W, House J. Committee on Hearing and Equilibrium guidelines for the evaluation of results of treatment of conductive hearing loss AmericanAcademy of Otolaryngology-Head and Neck Surgery Ffoundation, Inc. Otolaryngol - Head Neck Surg, 1995; 113(3): 186-87. 